\title{
Impact of Glass Industry Effluent Disposal on Soil Characteristics in Haridwar Region, India
}

\author{
Vinod Kumar*, Chopra, A.K, Sachin Srivastava, Vishvendra Tomar, Roushan K. Thakur, Jogendra \\ Singh
}

Agro-ecology and Pollution Research Laboratory, Department of Zoology and Environmental Science, Gurukula Kangri University, Haridwar, (Uttarakhand), India

"Corresponding author: Vinod Kumar, Agro-ecology and Pollution Research Laboratory, Department of Zoology and Environmental Science, Gurukula Kangri University, Haridwar-249404, Uttarakhand, India, E-mail: drvksorwal@gmail.com

\begin{abstract}
The present study was conducted to assess the impact of glass industry effluent on soil characteristics in the province of Asahi India glass Ltd. located in the Haridwar region, India. The results showed that the values of TS (1620.5 $\left.\mathrm{mg} \mathrm{L}^{-1}\right)$, TDS (1435.25 $\left.\mathrm{mg} \mathrm{L}^{-1}\right)$, TSS (364.25 $\left.\mathrm{mg} \mathrm{L}^{-1}\right)$, EC (1.34 dS m $\left.\mathrm{m}^{-1}\right)$, BOD (1447.75 $\left.\mathrm{mg} \mathrm{L}^{-1}\right)$, COD (3029.00 $\left.\mathrm{mg} \mathrm{L}^{-1}\right), \mathrm{Cl}^{-}\left(446.00 \mathrm{mg} \mathrm{L}^{-1}\right), \mathrm{Ca}^{2+}\left(164.47 \mathrm{mg} \mathrm{L}^{-1}\right), \mathrm{Cr}\left(7.64 \mathrm{mg} \mathrm{L}^{-1}\right), \mathrm{Cu}\left(2.06 \mathrm{mg} \mathrm{L}^{-1}\right)$, $\mathrm{Pb}\left(2.07 \mathrm{mgL}^{-1}\right)$ and $\mathrm{Zn}\left(0.44 \pm 0.08 \mathrm{mg} \mathrm{L}^{-1}\right)$ in the glass industry effluent were found beyond the prescribed limit of BIS standards. The glass industry effluent disposal decreased the moisture content, WHC and increased $\mathrm{pH}, \mathrm{EC}, \mathrm{Cl}^{-}, \mathrm{OC}, \mathrm{Na}^{+}, \mathrm{K}^{+}, \mathrm{Ca}^{2+}, \mathrm{Mg}^{2+}$, $\mathrm{TKN}, \mathrm{PO}_{4}^{3-}, \mathrm{SO}_{4}{ }^{2-}, \mathrm{Cd}, \mathrm{Cr}, \mathrm{Cu}, \mathrm{Fe}, \mathrm{Pb}$ and $\mathrm{Zn}$ of the soil in comparison to control soil. The contamination factor of heavy metals in the soil was recorded in the order of $\mathrm{Pb}>$ $\mathrm{Cd}>\mathrm{Cr}>\mathrm{Fe}>\mathrm{Zn}>\mathrm{Cu}$ after disposal of glass industry effluent. Among different heavy metals $\mathrm{Pb}$ (11.31) showed maximum contamination whereas $\mathrm{Cu}$ (2.23) showed minimum contamination. Therefore, the results indicated that the effluent of glass industry was rich in certain nutrients as well as heavy metals. Consequently, disposal of glass industry effluent significantly altered the soil quality and affected the natural composition of the soil.
\end{abstract}

Keywords: Glass industry effluent; Heavy metal; Pollution; Soil characteristics
Received date: May 14, 2016

Accepted date: August 24, 2016

Published date: August 31, 2016

Citation: Kumar, V., et al. Impact of Glass Industry Effluent Disposal on Soil Characteristics in Haridwar Region, India. (2016) J Environ Health Sci 2(2): 1- 8 .

DOI: $10.15436 / 2378-6841.16 .923$

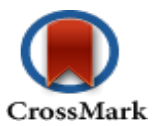

\section{Introduction}

Industrialization has become an important factor to the development of a country's economy, through the establishment of plants and factories [Megharaj, M., et al, 2003, Samuel, S., et al.2011]. However, the waste or by-products discharged from them are severely disastrous to the environment consists various kind of contaminant which contaminate the surface water, ground water and soil [Jain, C., et al 2005, Janardhana Raju, N., et al 2009, Kumar, V., et al 2011, Kumar, V., et al 2012c]. There are a number of reasons the waste are not safely treated. One of the reasons is mainly due to the lacking of highly efficient and economic treatment technology [Kumar, V., et al 2014a]. The focus of this chapter is to give a detail illustration at the effect of industrial discharge and on the environment and human health. Some corrective actions shall also be illustrated in the later part of this chapter; to overcome the contamination of industrial discharge [Ahmad, M., et al 2008, Baskaran, L., et al 2009, Kumar, V., et al 2014d] Aquatic ecosystems are still suffering from the large amount of hazardous compounds introduced into them by man. The presence of heavy metals in aquatic environment may render it unsuitable for some fauna and flora, and the potential risk of bioaccumulation along the food chain cannot be over emphasized [Zafar, S., et al 2007, Kumar, V., et al 2012a, Kumar, V., et al 2012b, Kumar, V., et al 2015]. Take for instance, many industries discharge raw, untreated and highly toxic wastes (effluents) into open gutters, drains, streams, ponds, canals, river, etc. Effects of this act have almost rendered many of our surface water system unsafe for domestic, agricultural, recreational and other beneficial uses, destroy life, poison the natural ecosystems and even threat to human life. Little wonder that water-related 
disease such as diarrhoea, cholera, typhoid fever, hepatitis, dysentery, guinea worm, poliomyelitis, skin diseases are rampant in the country, both in the urban and rural communities [Vijayaragavan, M., et al 2011]. Though, most importantly children, who normally have low immunity, and rural populace with poor healthcare facilities, are particularly vulnerable victims of these epidemics [Zafar, S., et al 2007, Srinivasa, Gowd, S., et al 2000, Tandi, N.K., et al 2004]. Pollution may be defined as undesirable changes in physical chemical and biological characteristics of soil, which are harmful for all living organisms. Environmental pollution is an emerging threat and of great concern in today's context pertaining to its effect on the ecosystem. Water pollution is one of the greatest concerns now a day. In recent years, considerable attention has been paid to industrial wastes discharged to land and surface water. Industrial effluent often contains various toxic metals, harmful dissolved gases, and several inorganic and organic compounds [Perfus Barbeoch, L., et al 2002, Purushotham, D., et al 2011].

The contamination of metals is a major environmental problem and especially in the aquatic environment [Kumar, V., et al 2014a, Kumar, V., et al 2014b, Kumar, V., et al 2014e]. Some metals are potentially toxic or carcinogenic even at very low concentration and are thus, hazardous to human if they enter the food chain [Biswas, A.K., et al 2009, Hati, K.M., et al 2007, Kumar, V., et al 2013b, Kumar, V., et al 2013c]. Metals are usually dissolved into the aquatic system through natural or anthropogenic sources. Metal ions are distributed thoroughly during their transport in different compartments of the aquatic ecosystems, in biotic or abiotic compartment such as fishes, water, sediment, plant. Metals remain in contaminated sediments may accumulate in microorganisms which in return entering into the food chain and eventually affect human well being [Shakeri, A., et al 2009, Kumar, V., et al 2013a, Kumar, V. et al 2014b, Baruah, B.K., et al 1998, Kumar, V., et al 2014c, Kumar, V., et al 2014].

The glass industry includes a variety of manufacturing facilities and products. It produces glass objects from a wide range of raw materials among which the most important ones are silica sand, glass cullet, and intermediate / modifying materials such as soda ash, limestone, dolomite, and feldspar [Werner, V, et al 1994]. The most significant water use occurs during cooling and cullet cleaning. As a result liquid effluents discharged from glass manufacture industries. Discharges may be affected by glass solids, some soluble glass-making materials (e.g. sodium sulfate), some organic compounds caused by lubricant oil used in the cutting process, and treatment chemicals (e.g. dissolved salts and water treatment chemicals) for the cooling-water system [Werner, V, et al 1994]. Metal emission is an important issue in some sub-sectors (e.g. lead crystal and frits production); however, this problem is present in all other glass manufacturing sectors to a lesser degree. Heavy metals may be present as minor impurities in some raw materials, in cullet, and in fuels. Lead and cadmium are used in fluxes and coloring agents in the frit industry. Particulates from lead crystal manufacture may have a lead content of $20-60$ percent. Special glass manufactures may release arsenic, antimony, and selenium (the coloring agent in bronze glass or decolouring agent in some clear glasses). In the recent past various studies has been made on the effects of different industrial effluent on soil characteristics [Jain, C., et al 2005, Zafar, S., et al 2007, Tandi, N.K., et al 2004, Hati, K.M., et al 2007, Kumar, V., et al 2004]. But there is scanty of scientif- ic reports of impact of glass industry effluent on soil properties [Shakeri, A., et al 2009, Kumar, V. et al 2014b]. Keeping in view of effluent generation and their effects on soil properties the present investigation was conducted to study the physico-chemical characteristics of Asahi India Glass Ltd. Industry effluent and assess its pollution load and to study the impact of glass industry effluent disposal on physico-chemical characteristics.

\section{Materials and Methods}

\section{Study area, collection of effluent samples and analysis}

The Asahi India Glass Ltd. Jhabrera, Roorkee, Haridwar $\left(29^{\circ} 47^{\prime} 50^{\prime \prime} \mathrm{N} 77^{\circ} 48^{\prime} 23^{\prime \prime} \mathrm{E}\right)$ was selected for the collection of effluent samples. The glass industry is located about $45 \mathrm{Km}$ away from Haridwar at Haridwar Saharanpur via Jhabrera Highway. For analysis of various physico-chemical and parameters the effluent samples were collected from the effluent disposal channel. The samples were collected in thoroughly cleaned plastic container of 5 liters capacity provides with the double cap device. Some of the parameters like $\mathrm{pH}$ were carried out on the spot and dissolved oxygen (DO) was also fixed on the spot because time consumed during transportation could alter the results. Remaining parameters could be carried out on composite sample. The collected samples were brought to the laboratory and were analyzed for various physico-chemical parameters viz., total solids (TS), total dissolved solids (TDS), total suspended solids (TSS), electrical conductivity (EC), $\mathrm{pH}, \mathrm{DO}$, bio-chemical oxygen demand (BOD), chemical oxygen demand (COD), chlorides $(\mathrm{Cl})$, calcium $\left(\mathrm{Ca}^{2+}\right)$, sodium $\left(\mathrm{Na}^{+}\right)$, potassium $\left(\mathrm{K}^{+}\right)$, magnesium $\left(\mathrm{Mg}^{2+}\right)$, total Kjehldahl nitrogen (TKN), phosphate $\left(\mathrm{PO}_{4}^{3-}\right)$ and sulfate $\left(\mathrm{SO}_{4}^{2-}\right)$ and heavy metals like cadmium $(\mathrm{Cd})$, chromium $(\mathrm{Cr})$, copper $(\mathrm{Cu})$, iron $(\mathrm{Fe})$, lead $(\mathrm{Pb})$ and zinc $(\mathrm{Zn})$ following standard techniques [APHA In, 2005, Chaturvedi, R.K.,et al 2006].

\section{Soil sampling and analysis:}

Total six composite soil samples from the surface $(0-20$ $\mathrm{cm})$ were collected in the vicinity of effluent disposal channel originated from Asahi India Glass Ltd. The bore well water irrigated soil was taken as control. The samples were brought to the laboratory and dried in clean plastic trays for 7 days at room temperature and then sieved through a $2-\mathrm{mm}$ or $5-\mathrm{mm}$ sieve. The samples were analyzed for various physico-chemical parameters namely soil moisture content, water holding capacity (WHC), bulk density (BD), $\mathrm{pH}, \mathrm{EC}, \mathrm{Cl}^{-}$, organic carbon (OC), $\mathrm{Na}^{+}, \mathrm{K}^{+}$, $\mathrm{Ca}^{2+}, \mathrm{Mg}^{2+}, \mathrm{TKN}, \mathrm{PO}_{4}^{3-}, \mathrm{SO}_{4}^{2-}, \mathrm{Cd}, \mathrm{Cr}, \mathrm{Cu}, \mathrm{Fe}, \mathrm{Pb}$ and $\mathrm{Zn}$ following standard methods [Chaturvedi, R.K.,et al 2006].

\section{Heavy metal analysis:}

For heavy metals analysis $10 \mathrm{ml}$ sample of effluent, 100 $\mathrm{ml}$ sample of bore well water and $0.5 \mathrm{~g}$ sample of soil was digested with a mixture of concentrated $\mathrm{HNO}_{3}$ and $\mathrm{HClO}_{4}(10 \mathrm{ml}$ $+2 \mathrm{ml}$ ) separately. The digested samples were filtered through Whatman filter No. 42 and finally volume were made $50 \mathrm{ml}$ with $0.1 \mathrm{~N} \mathrm{HNO}_{3}$ and analyzed for heavy metals using AAS (Model ECIL-4129). The contamination of heavy metals in the soil was determined by following the standard methods [Håkanson, L, 1980].

Contamination factor $(\mathrm{Cf})=\frac{\text { Mean content of metal in the sample }}{\text { Background metal content of the substance }}$ 


\section{Data interpretation and statistical analysis:}

Data were analyzed for one way analysis of variance (ANOVA) for determining the difference between soil parameters before and after effluent irrigation, crop parameters and effluent concentration, standard deviation, coefficient of correlation for soil, crop parameters and effluent concentrations were also calculated with the help of MS Excel 2003, SPSS12.0 and Sigma plot, 2000.

\section{Results and Discussion}

\section{Characteristics of glass industry effluent:}

During the present study the values of total solids (TS), total dissolved solids (TDS) and total suspended solids (TSS) in the glass industry effluent were recorded to be significantly $(\mathrm{P}<$ 0.05 ) different in comparison to the values of groundwater (Table 1 Figure 1). Kumar and Chopra et al 2014 recorded the more values of TS $\left(860 \mathrm{mgL}^{-1}\right)$ in the paper mill effluent while Baruah and Das 1998, also found the higher values of TDS (1945.44 $\left.\mathrm{mgL}^{-1}\right)$, TSS (245.50 $\left.\mathrm{mgL}^{-1}\right)$ in the paper mill effluent. Moreover, the values of TS $\left(2100 \mathrm{mgL}^{-1}\right)$ and TDS $\left(1900 \mathrm{mgL}^{-1}\right)$ were found within the permissible limit while the values of TSS (200) was recorded beyond the prescribed limit of BIS standards for inland disposal of treated water.

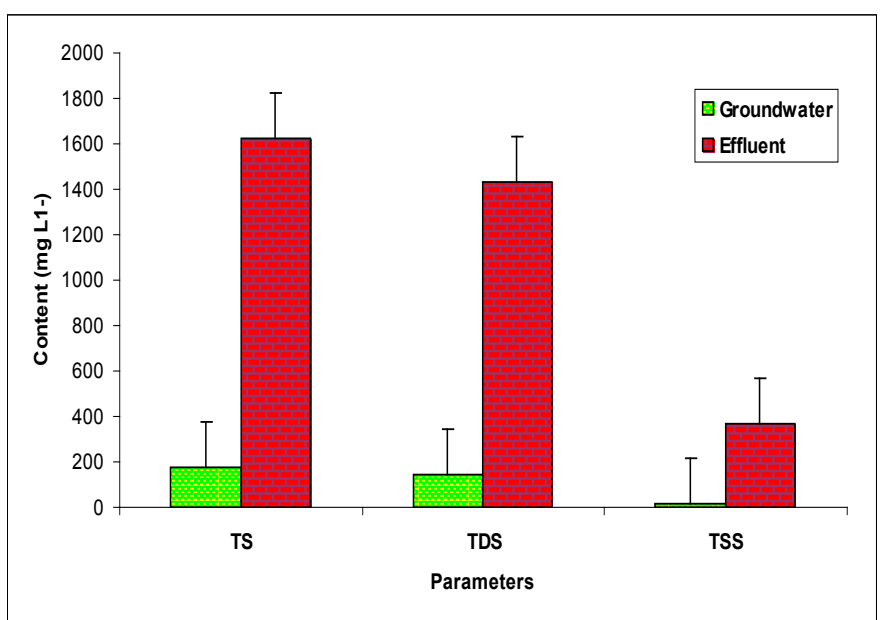

Figure 1: The contents of TS, TDS and TSS in the glass industry effluent. Error bars are the standard error of the mean.

The value of electrical conductivity (EC) was observed $\left(1.34 \mathrm{dS} \mathrm{m}^{-1}\right)$ in the glass industry effluent was recorded higher in contrast to the value of the EC $\left(0.10 \mathrm{dS} \mathrm{m}^{-1}\right)$ in the groundwater. The higher values of EC $\left(8.84 \mathrm{dS} \mathrm{m}^{-1}\right)$ were also reported by Kumar and Chopra 2014, in the distillery effluent. The value of $\mathrm{pH}$ (8.07) of the glass industry effluent was recorded to be more alkaline in comparison to the $\mathrm{pH}$ (7.61) of the groundwater and the value of $\mathrm{pH}$ was found within the range of the $\mathrm{pH}(6.5$ - 8.5 and 5.5 - 9.0) prescribed by BIS for irrigation water. The findings were in accordance with El-Bestawy et al. 2008 who reported the alkaline $\mathrm{pH}$ of the paper mill effluent. The value of dissolved oxygen in the glass industry effluent was observed to be nil. Therefore, the glass industry effluent was not suitable for inland disposal. Kumar and Chopra 2014c, also found the lower values of DO $\left(4.78 \mathrm{mgL}^{-1}\right)$ in the treated sugar mill effluent.

The values of BOD, COD and chlorides was recorded significantly $(\mathrm{P}<0.01)$ higher in the glass industry effluent when compared to the values of groundwater and it is likely due to the presence of more inorganic and organic load in the glass industry effluent (Table 1 Figure 2). The value of BOD $\left(4.0 \mathrm{mg} \mathrm{L}^{-1}\right.$ and $\left.100 \mathrm{mg} \mathrm{L}^{-1}\right)$ and COD $\left(250 \mathrm{mg} \mathrm{L}^{-1}\right)$ was found beyond the prescribed limit of BIS standards for irrigation water. Fazeli et al. 1998 also reported the higher values of BOD $\left(1840.50 \mathrm{mgL}^{-}\right.$ $\left.{ }^{1}\right)$ in the paper mill effluent whereas, Ghaly et al. 2011 reported the more COD (2450.60 $\left.\mathrm{mgL}^{-1}\right)$ in the paper mill effluent. Howe et al. 1996 who observed the higher values of chlorides $(360.00$ $\left.\mathrm{mgL}^{-1}\right)$ in the paper mill effluent. The values of $\mathrm{Na}^{+}, \mathrm{K}^{+}, \mathrm{Ca}^{2+}$, $\mathrm{Mg}^{2+}, \mathrm{TKN}, \mathrm{PO}_{4}^{3-}$ and $\mathrm{SO}_{4}{ }^{2-}$ in the glass industry effluent were observed to be significantly $(\mathrm{P}<0.01)$ higher in comparison to the values of there parameters in the groundwater (Table 1 Figure $3)$. The contents of TKN (22.68 $\left.\mathrm{mg} \mathrm{L}^{-1}\right), \mathrm{PO}_{4}{ }^{3-}\left(7.79 \mathrm{mg} \mathrm{L}^{-1}\right)$ and $\mathrm{SO}_{4}^{2-}\left(878 \mathrm{mg} \mathrm{L}^{-1}\right)$ in the glass industry effluent were observed to be significantly $(\mathrm{P}<0.05)$ higher in comparison to the contents of TKN (1.59 $\left.\mathrm{mg} \mathrm{L}^{-1}\right), \mathrm{PO}_{4}{ }^{3-}\left(0.42 \mathrm{mg} \mathrm{L}^{-1}\right)$ and $\mathrm{SO}_{4}{ }^{2-}(340.25 \mathrm{mg}$ $\left.\mathrm{L}^{-1}\right)$ in the groundwater. Kumar and Chopra 2014, also reported the more $\mathrm{Na}^{+}, \mathrm{K}^{+}, \mathrm{Ca}^{2+}, \mathrm{Mg}^{2+}, \mathrm{TKN}, \mathrm{PO}_{4}{ }^{3-}$ and $\mathrm{SO}_{4}{ }^{2-}$ in the sugar mill effluent while Lacorte et al. 2003 also reported the more sulphate in the paper mill effluent.

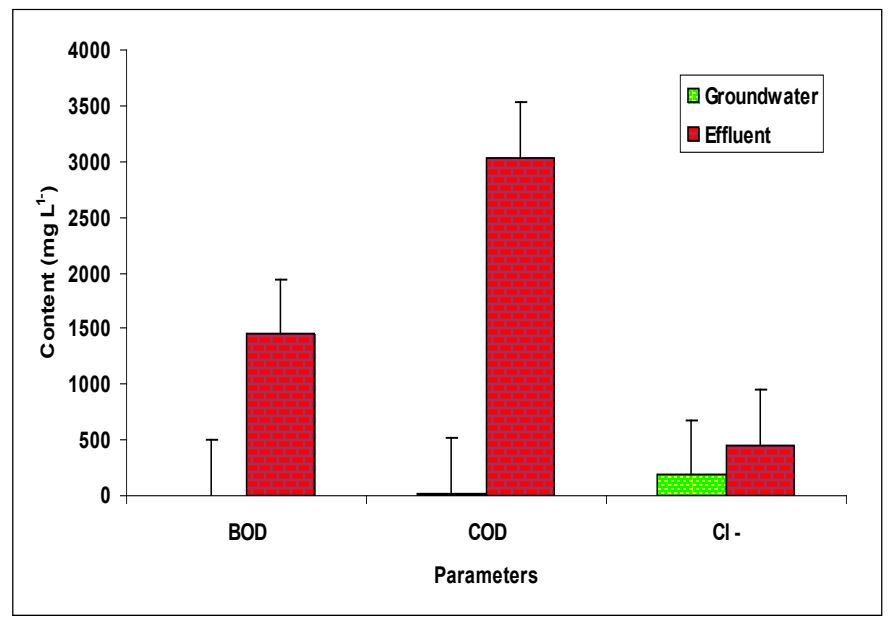

Figure 2: The contents of BOD, $\mathrm{COD}$ and $\mathrm{Cl}^{-}$in the glass industry effluent. Error bars are the standard error of the mean.

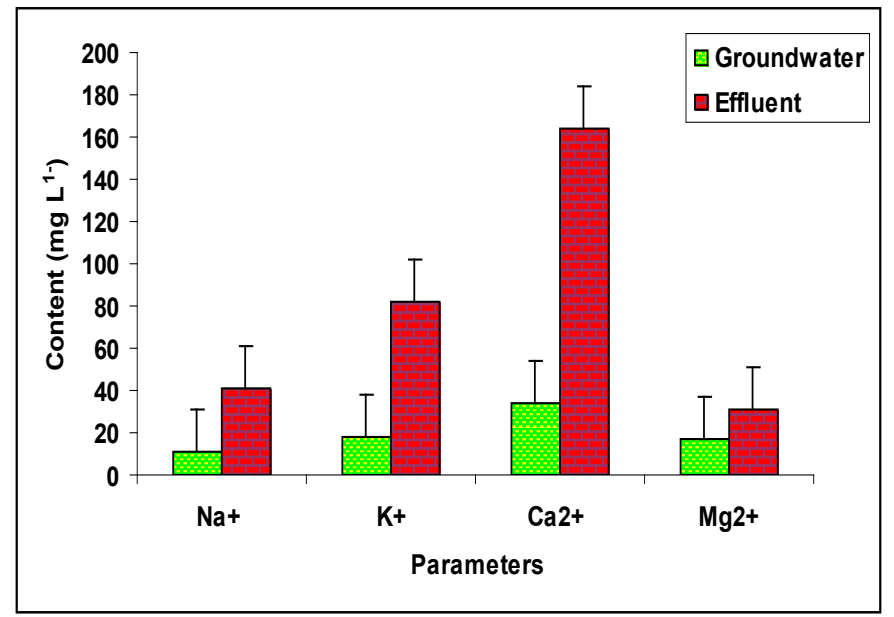

Figure 3: The contents of $\mathrm{Na}^{+}, \mathrm{K}^{+}, \mathrm{Ca}^{2+}$ and $\mathrm{Mg}^{2+}$ in the glass industry effluent. Error bars are the standard error of the mean. 


\section{Contents of heavy metals in the glass industry effluent:}

In the present study the value of $\mathrm{Cd}, \mathrm{Cr}, \mathrm{Cu}, \mathrm{Fe}, \mathrm{Pb}$ and $\mathrm{Zn}$ in the glass industry effluent were recorded to be significantly higher in comparison to the values of $\mathrm{Cd}, \mathrm{Cr}, \mathrm{Cu}, \mathrm{Fe}, \mathrm{Pb}$ and $\mathrm{Zn}$ observed in the groundwater (Table 1 Figure 4) The value of $\mathrm{Cd}\left(1.5 \mathrm{mg} \mathrm{L}^{-1}\right),\left(2.0 \mathrm{mg} \mathrm{L}^{-1}\right), \mathrm{Cu}\left(1.0 \mathrm{mg} \mathrm{L}^{-1}\right), \mathrm{Fe}\left(15 \mathrm{mg} \mathrm{L}^{-1}\right)$, $\mathrm{Pb}\left(3.00 \mathrm{mg} \mathrm{L}^{-1}\right)$ and $\mathrm{Zn}\left(1.00 \mathrm{mg} \mathrm{L}^{-1}\right)$ were found beyond the prescribed limit of BIS standards for irrigation water. The heavy metals are at very low concentrations in the natural environment, and they are typically introduced to surface waters as waste from human activities. Some of the metals of concern for human and aquatic health are cadmium, lead, copper, mercury, selenium, and chromium etc. The findings were in agreement with Patterson et al. 2008, who reported more values of heavy metals in the paper mill effluent.

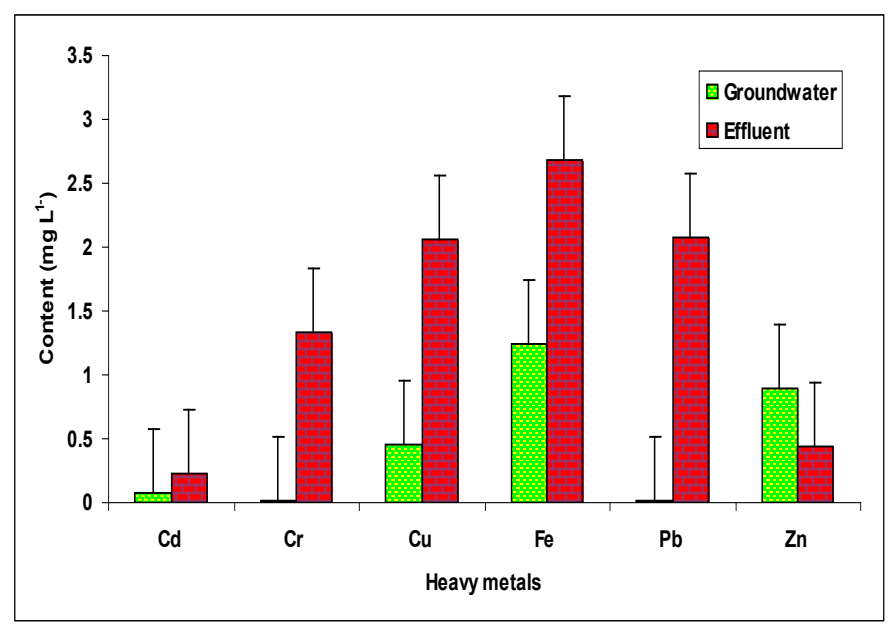

Figure 4: The contents of $\mathrm{Cd}, \mathrm{Cr}, \mathrm{Cu}, \mathrm{Fe}, \mathrm{Pb}$ and $\mathrm{Zn}$ in the glass industry effluent. Error bars are the standard error of the mean.

Table 1: Physico-chemical characteristics of control (Bore well water) and Glass industry effluent.

\begin{tabular}{|c|c|c|c|c|}
\hline Parameter & Borewell water & Effluent & BIS for drinking water & BIS for irrigation water \\
\hline TS $\left(\mathrm{mg} \mathrm{L}^{-1}\right)$ & $178.25 \pm 4.65$ & $1620.5 \pm 7.72$ & 600 & 2100 \\
\hline $\operatorname{TDS}\left(\mathrm{mg} \mathrm{L}^{-1}\right)$ & $140.25 \pm 9.07$ & $1435.25 \pm 9.36$ & 500 & 1900 \\
\hline $\operatorname{TSS}\left(\mathrm{mg} \mathrm{L}^{-1}\right)$ & $20.00 \pm 3.65$ & $364.25 \pm 6.95$ & 100 & 200 \\
\hline$E C\left(d S m^{-1}\right)$ & $0.10 \pm 0.03$ & $1.34 \pm 0.19$ & - & - \\
\hline pH & $7.61 \pm 0.30$ & $8.07 \pm 0.45$ & $6.5-8.5$ & $5.5-9.0$ \\
\hline $\operatorname{DO}\left(\mathrm{mg} \mathrm{L}^{-1}\right)$ & $8.64 \pm 1.25$ & NIL & $6-8$ & - \\
\hline $\operatorname{BOD}\left(\mathrm{mg} \mathrm{L}^{-1}\right)$ & $5.30 \pm 0.78$ & $1447.75 \pm 8.34$ & 4.0 & 100 \\
\hline $\operatorname{COD}\left(\mathrm{mg} \mathrm{L}^{-1}\right)$ & $18.77 \pm 1.73$ & $3029.00 \pm 18.31$ & $150-200$ & 250 \\
\hline $\mathrm{Cl}^{-}\left(\mathrm{mg} \mathrm{L}^{-1}\right)$ & $183.00 \pm 2.58 .00$ & $446.00 \pm 9.38$ & 250 & 500 \\
\hline $\mathrm{Na}^{+}\left(\mathrm{mg} \mathrm{L}^{-1}\right)$ & $11.40 \pm 1.46$ & $40.92 \pm 2.95$ & - & - \\
\hline $\mathrm{K}^{+}\left(\mathrm{mg} \mathrm{L}^{-1}\right)$ & $18.38 \pm 1.65$ & $82.10 \pm 3.05$ & - & - \\
\hline $\mathrm{Ca}^{2+}\left(\mathrm{mg} \mathrm{L}^{-1}\right)$ & $34.27 \pm 1.96$ & $164.47 \pm 8.91$ & 75 & 200 \\
\hline $\mathrm{Mg}^{2+}\left(\mathrm{mg} \mathrm{L}^{-1}\right)$ & $17.50 \pm 2.11$ & $31.30 \pm 3.72$ & - & - \\
\hline TKN (mg L-1) & $1.59 \pm 0.31$ & $22.68 \pm 3.29$ & & 100 \\
\hline $\mathrm{PO}_{4}^{3-}\left(\mathrm{mg} \mathrm{L}^{-1}\right)$ & $0.42 \pm 0.19$ & $7.79 \pm 0.20$ & - & - \\
\hline $\mathrm{SO}_{4}^{2-}\left(\mathrm{mg} \mathrm{L}^{-1}\right)$ & $340.25 \pm 4.26$ & $878.00 \pm 13.73$ & 200 & 1000 \\
\hline $\operatorname{Cd}\left(\mathrm{mg} \mathrm{L}^{-1}\right)$ & ND & $0.23 \pm 0.2275$ & 0.05 & 1.5 \\
\hline $\operatorname{Cr}\left(\mathrm{mg} \mathrm{L}^{-1}\right)$ & ND & $7.64 \pm 8.0725$ & 0.05 & 2.0 \\
\hline $\mathrm{Cu}\left(\mathrm{mg} \mathrm{L}^{-1}\right)$ & $0.45 \pm 0.08$ & $2.06 \pm 0.82$ & 0.30 & 1.0 \\
\hline $\mathrm{Fe}\left(\mathrm{mg} \mathrm{L}^{-1}\right)$ & $1.25 \pm 0.32$ & $2.68 \pm 0.61$ & 5.00 & 15 \\
\hline $\mathrm{Pb}\left(\mathrm{mg} \mathrm{L}^{-1}\right)$ & $0.01 \pm 0.01$ & $2.07 \pm 0.01$ & 0.05 & 3.00 \\
\hline $\operatorname{Zn}\left(\mathrm{mg} \mathrm{L}^{-1}\right)$ & $0.00 \pm 0.01$ & $0.44 \pm 0.08$ & 0.05 & 1.00 \\
\hline
\end{tabular}

Mean \pm SD of six values; BWW - Borewell water; BIS- Bureau of Indian standard; ND-Not detected.

Effects of glass industry effluent disposal on soil characteristics:

The value of soil moisture content $(33.52 \pm 2.47 \%)$ and WHC $(40.81 \%)$ of the glass industry effluent irrigated soil was decreased in comparison to the moisture content $(41.85 \%)$ and WHC $(44.84 \%)$ of the groundwater irrigated soil. recorded in the glass industry effluent contaminated soil. Miller and Turk 2002, have indicated that the moisture content of soil is useful and an important factor which affects the $\mathrm{pH}$, availability of nutrients to plant and aeration. Moreover, the presence of large soil particles reduces the soil moisture content. In the present study there was no drastic change in the bulk density $(1.43 \pm 0.10 \mathrm{gm}$ $\mathrm{cm}^{-3}$ ) of the soil after glass industry effluent disposal. Haynes and Naidu 1998 and Celik et al 2005 reported a reduction in BD with addition of organic matter. The reduction in BD (uniformly repacked) was due to higher organic matter content in the treatments where paper mill effluent was added.

The EC $\left(1.96 \pm 0.07 \mathrm{dS} \mathrm{m}^{-1}\right)$ of the glass industry effluent contaminated soil was significantly $(\mathrm{P}<0.01)$ increased to $125.28 \%$ when compared to groundwater irrigated soil. The 
increase in the EC of the effluent irrigated soil is likely due to the presence of more salts in the glass industry effluent [Kumar, V., et al 2013b]. Mohan et al. 2007 concluded that the EC of water and wastewater is due to the presence of total dissolved solids. It is an important criterion to determine the suitability of water and waste water for irrigation. Soils have alkaline $\mathrm{pH}$ levels that are greater than 7 . If these soils have excessive amount of salts (i.e. EC $>4 \mathrm{dS} \mathrm{m}^{-1}$ ) they are classified as saline soils. The $\mathrm{pH}$ of the glass industry effluent contaminated soil was recorded to be more alkaline $(8.14)$ with the insignificantly $(P>0.05)$ increase to $3.82 \%$ in comparison to control soil. Charman and Murphy 1991 , reported that the basic $\mathrm{pH}$ of the soil is to reduce the solubility of all micronutrients (except chlorine, boron and molybdenum), especially those of iron, zinc, copper and manganese.

During the present study the values of $\mathrm{Cl}^{-}, \mathrm{PO}_{4}{ }^{3-}, \mathrm{SO}_{4}{ }^{2-}$, $\mathrm{Na}^{+}, \mathrm{K}^{+}, \mathrm{Ca}^{2+}, \mathrm{Mg}^{2+}$, in the glass industry effluent contaminated soil was significantly $(\mathrm{P}<0.01)$ increased in comparison to the control soil (Table 2, Figures 5,6). The content of $\mathrm{Cl}^{-}$ (75.01\%), $\mathrm{PO}_{4}^{3-}(235.51 \%), \mathrm{SO}_{4}^{2-}(29.79 \%), \mathrm{Na}^{+}(106.49 \%), \mathrm{K}^{+}$ (34.19\%), $\mathrm{Ca}^{2+}(122.73 \%), \mathrm{Mg}^{2+}(144.54 \%), \mathrm{TKN}(45.16 \%)$ and OC $(34.61 \%)$ increased in comparison to the groundwater irrigated soil. The contents of TKN (43.49 $\left.\mathrm{mg} \mathrm{Kg}^{-1}\right)$ and OC $(0.35$ $\left.\mathrm{mg} \mathrm{Kg}{ }^{-1}\right)$ were significantly $(\mathrm{P}<0.05)$ increased in the glass industry effluent irrigated soil when compared to the values of TKN (29.96 mg Kg $\left.{ }^{-1}\right)$ and OC $\left(0.26 \mathrm{mg} \mathrm{Kg}^{-1}\right)$ in the control soil. Kumar and Chopra 2013a reported the higher values of $\mathrm{Cl}^{-}$ and TKN in the paper mill effluent irrigated soul in comparison to bore well water irrigated soil. Biswas et al. 2009 recorded the more values of sodium and calcium in the distillery effluent irrigated soil. Baskaran et al. 2009 reported the higher values of $\mathrm{Mg}^{2+}$ in the sugar mill effluent irrigated soil. Effluent irrigation generally adds significant quantities of salts to the soil environment, such as sulfates, phosphates, bicarbonates, chlorides of the cations sodium, calcium, potassium and magnesium that stimulate the growth at lower concentration but inhibit at higher concentration reported by Patterson et al. 2008. Miller and Turk 2002 reported that potassium is the third most commonly added fertilizer nutrient (nitrogen is the most used; phosphorus is the second). Potassium is known to affect cell division, cell permeability formation of carbohydrates, translocation of sugars, various enzyme actions and resistance of some plants to certain diseases. Biswas et al 2009, recorded the more values of organic carbon, phosphate and sulphate in the distillery effluent irrigated soil.

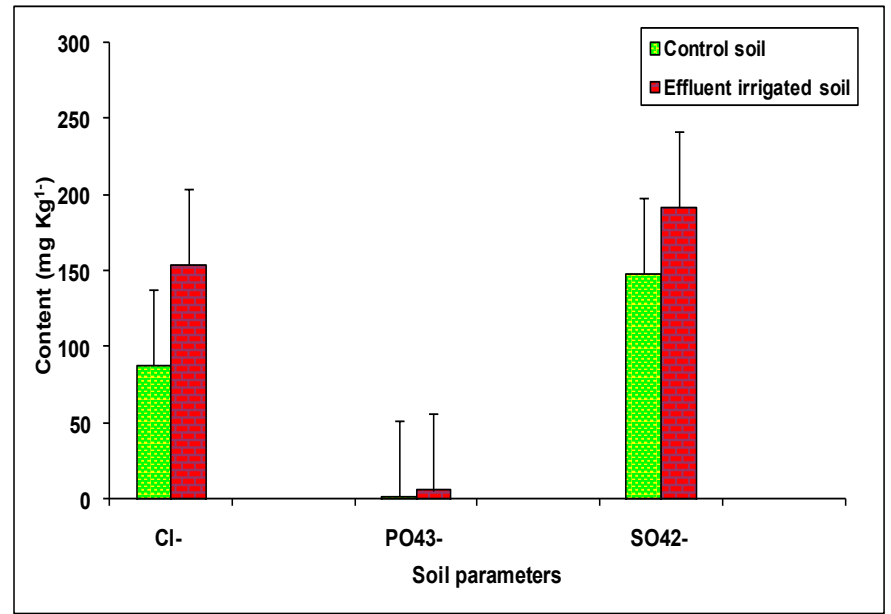

Figure 5: The contents of $\mathrm{Cl}^{-}, \mathrm{PO}_{4}{ }^{3-}$ and $\mathrm{SO}_{4}{ }^{2-}$ in the glass industry effluent irrigated soil. Error bars are the standard error of the mean.

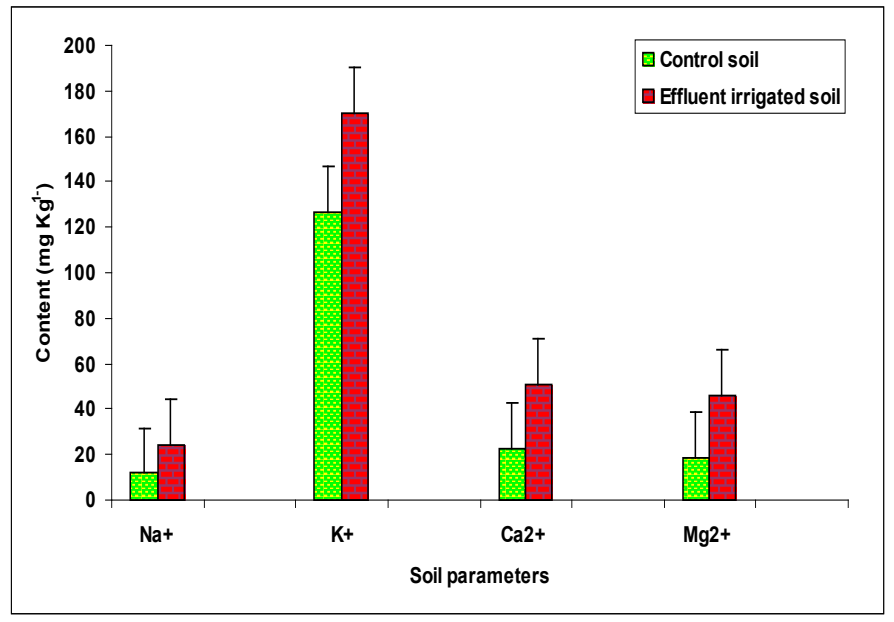

Figure 6: The contents of $\mathrm{Na}^{+}, \mathrm{K}^{+}, \mathrm{Ca}^{2+}$ and $\mathrm{Mg}^{2+}$ in the glass industry effluent irrigated soil. Error bars are the standard error of the mean.

Table 2: Physico-chemical characteristics of soil before and after disposal of Glass industry effluent.

\begin{tabular}{|c|c|c|c|c|}
\hline Soil moisture (\%) & $41.85 \pm 2.62$ & $\begin{array}{c}33.52 \mathrm{a} \pm 2.47 \\
(-19.90)\end{array}$ & $7.071291^{*}$ & 3.182446 \\
\hline WHC (\%) & $44.84 \pm 3.50$ & $\begin{array}{c}40.81 \pm 3.21 \\
(-8.98)\end{array}$ & $2.661559^{\mathrm{NS}}$ & 3.182446 \\
\hline BD $\left(\mathrm{gm} \mathrm{cm}^{-3}\right)$ & $1.43 \pm 0.10$ & $\begin{array}{c}1.43 \pm 0.10 \\
(0.00)\end{array}$ & $0.253849^{\mathrm{NS}}$ & 3.182446 \\
\hline pH & $7.84 \pm 0.13$ & $\begin{array}{c}8.14 \pm 0.15 \\
(+3.82)\end{array}$ & $2.29528^{\mathrm{NS}}$ & 3.182446 \\
\hline$E C\left(d S m^{-1}\right)$ & $0.87 \pm 0.04$ & $\begin{array}{c}1.96 \mathrm{a} \pm 0.07 \\
(+125.28)\end{array}$ & $26.4928^{*}$ & 3.182446 \\
\hline $\mathrm{Cl}^{-}\left(\mathbf{m g ~ K g} \mathbf{~ K}^{-1}\right)$ & $88.05 \pm 9.54$ & $\begin{array}{c}154.10 \mathrm{a} \pm 6.98 \\
(+75.01)\end{array}$ & $10.216^{*}$ & 3.182446 \\
\hline $\mathrm{OC}\left(\mathrm{mg} \mathrm{Kg} \mathbf{g}^{-1}\right)$ & $0.26 \pm 0.03$ & $\begin{array}{c}0.35 \mathrm{a} \pm 0.02 \\
(+34.61)\end{array}$ & $2.1273 *$ & 3.182446 \\
\hline $\mathrm{Na}^{+}\left(\mathrm{mg} \mathrm{Kg}^{-1}\right)$ & $11.85 \pm 1.96$ & $\begin{array}{c}24.47 \mathrm{a} \pm 3.70 \\
(+106.49)\end{array}$ & $4.82924 *$ & 3.182446 \\
\hline $\mathrm{K}^{+}\left(\mathbf{m g ~ K g} \mathbf{g}^{-1}\right)$ & $126.91 \pm 4.46$ & $\begin{array}{c}170.31 \mathrm{a} \pm 4.27 \\
(+34.19)\end{array}$ & $16.3426^{*}$ & 3.182446 \\
\hline $\mathrm{Ca}^{2+}\left(\mathrm{mg} \mathrm{Kg}^{-1}\right)$ & $22.87 \pm 1.66$ & $\begin{array}{c}50.94 \pm 4.96 \\
(+122.73)\end{array}$ & $7.36417^{*}$ & 3.182446 \\
\hline
\end{tabular}


Impact of Glass Industry Effluent Disposal on Soil Characteristics

\begin{tabular}{|c|c|c|c|c|}
\hline $\mathrm{Mg}^{2+}\left(\mathrm{mg} \mathrm{Kg} \mathrm{g}^{-1}\right)$ & $18.70 \pm 1.51$ & $\begin{array}{c}45.73 \mathrm{a} \pm 2.29 \\
(+144.54)\end{array}$ & $12.4942^{*}$ & 3.182446 \\
\hline TKN (mg Kg $\left.\mathbf{K g}^{-1}\right)$ & $29.96 \pm 3.38$ & $\begin{array}{c}43.49 \mathrm{a} \pm 2.54 \\
(+45.16)\end{array}$ & $9.98271^{*}$ & 3.182446 \\
\hline $\mathrm{PO}_{4}{ }^{3-}\left(\mathrm{mg} \mathrm{Kg}^{-1}\right)$ & $1.83 \pm 0.56$ & $\begin{array}{c}6.14 \mathrm{a} \pm 0.37 \\
(+235.51)\end{array}$ & $18.8531^{*}$ & 3.182446 \\
\hline $\mathrm{SO}_{4}{ }^{2-}\left(\mathrm{mg} \mathrm{Kg}^{-1}\right)$ & $148.06 \pm 6.32$ & $\begin{array}{c}192.17 \mathrm{a} \pm 5.58 \\
(+29.79)\end{array}$ & $8.22161^{*}$ & 3.182446 \\
\hline $\mathrm{Cd}\left(\mathrm{mg} \mathrm{Kg} \mathrm{g}^{-1}\right)$ & $0.105 \pm 0.00$ & $\begin{array}{c}1.085 \mathrm{a} \pm 0.28 \\
(+933.33)\end{array}$ & $7.11562 *$ & 3.182446 \\
\hline $\mathrm{Cr}\left(\mathrm{mg} \mathrm{Kg} \mathrm{Kg}^{-1}\right)$ & $0.068 \pm 0.05$ & $\begin{array}{c}0.690 \mathrm{a} \pm 0.40 \\
(+2082.85)\end{array}$ & $3.26848^{*}$ & 3.182446 \\
\hline $\mathrm{Cu}\left(\mathrm{mg} \mathrm{Kg}^{-1}\right)$ & $1.040 \pm 0.03$ & $\begin{array}{c}2.329 \mathrm{a} \pm 0.19 \\
(+115.47)\end{array}$ & $15.1429^{*}$ & 3.182446 \\
\hline $\mathrm{Fe}\left(\mathrm{mg} \mathrm{Kg} \mathrm{g}^{-1}\right)$ & $1.05 \pm 0.03$ & $\begin{array}{c}3.20 \mathrm{a} \pm 0.09 \\
(+107.81)\end{array}$ & $32.0249^{*}$ & 3.182446 \\
\hline $\mathrm{Pb}\left(\mathbf{m g ~ K g ^ { - 1 }}\right)$ & $0.185 \pm 0.04$ & $\begin{array}{c}2.093 \mathrm{a} \pm 0.50 \\
(+1031.35)\end{array}$ & $7.21127^{*}$ & 3.182446 \\
\hline $\mathrm{Zn}\left(\mathbf{m g ~ K g} \mathbf{g}^{-1}\right)$ & $1.154 \pm 0.06$ & $\begin{array}{c}3.370 \mathrm{a} \pm 0.25 \\
(+192.02)\end{array}$ & $17.8929^{*}$ & 3.182446 \\
\hline
\end{tabular}

Mean \pm SD of six values; Significant t at $* \mathrm{P}>5 \%$ level; \% Increase or decrease in comparison to the control given in parenthesis; a - significantly different to the control; NS - Not Significant.

\section{Contents of heavy metals in the glass industry effluent irri- gated soil}

Soil contamination is the result of anthropogenic activities, including the entry of industrial wastes into soil through atmospheric deposition or application of agrochemicals and dumping of domestic waste to the land. These contaminants reduce the soil quality for agricultural production. The soil is a long-term sink for the group of potentially toxic elements often referred to as heavy metals like zinc, copper, nickel, lead, chromium, and cadmium. While these elements display a range of properties in agricultural soil, including differences in mobility and bioavailability, leaching losses and plant uptake are usually relatively small compared to the total quantities entering the soil from different diffuse and agricultural sources.

During the investigation, the values of $\mathrm{Cd}, \mathrm{Cr}, \mathrm{Cu}, \mathrm{Fe}$, $\mathrm{Pb}$ and $\mathrm{Zn}$ in the glass industry effluent contaminated soil were observed to be significantly $(\mathrm{P}<0.05)$ higher when compared to the groundwater irrigated soil (Table 2, Figure. 7). The values of these metals $\mathrm{Cd}(933.33 \%), \mathrm{Cr}(2082.85 \%), \mathrm{Cu}(2.329 \pm 0.19 \%)$, $\mathrm{Fe}(107.81 \%), \mathrm{Pb}(1031.35 \%), \mathrm{Zn}(192.02 \%)$ were increased significantly $(\mathrm{P}<0.05)$ in the glass industry effluent contaminated soil in comparison to the control soil. Among different heavy metals $\mathrm{Pb}$ (11.31) showed maximum contamination whereas $\mathrm{Cu}$ (2.23) showed minimum contamination. The contamination factor of heavy metals in the soil was recorded in the order of $\mathrm{Pb}>$ $\mathrm{Cd}>\mathrm{Cr}>\mathrm{Fe}>\mathrm{Zn}>\mathrm{Cu}$ after disposal of glass industry effluent (Table 3, Figure. 8). Additionally, the increase in the contents of $\mathrm{Cd}, \mathrm{Cr}, \mathrm{Cu}, \mathrm{Fe}, \mathrm{Zn}$ and $\mathrm{Pb}$ are likely due to the presence of more concentration of these metals in the glass industry effluent. The contents of heavy metals in the glass industry effluent contaminated soil were found to be below the maximum levels permitted for $\mathrm{Cd}$ (6.0 mg Kg-1), Cr (10.0 mg Kg $\left.{ }^{-1}\right), \mathrm{Cu}\left(270 \mathrm{mg} \mathrm{Kg}^{-1}\right), \mathrm{Fe}$ (1000 mg Kg $\left.{ }^{-1}\right), \mathrm{Pb}\left(250 \mathrm{mg} \mathrm{Kg}^{-1}\right)$ and $\mathrm{Zn}\left(600 \mathrm{mg} \mathrm{Kg}^{-1}\right)$ for soil in India [BIS In, 1991]. Mohammadi et al. 2010 concluded that the use of paper mill lime sludge as a soil amendment in an acidic soil significantly increased $\mathrm{pH}$, which was proportional to the application rate of paper mill sludge.

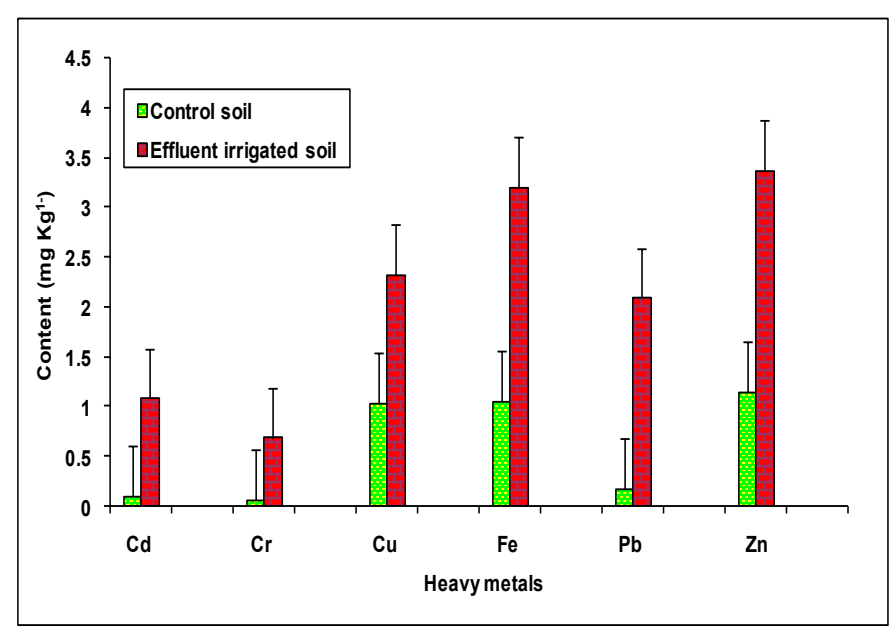

Figure 7: The contents of $\mathrm{Cd}, \mathrm{Cr}, \mathrm{Cu}, \mathrm{Fe}, \mathrm{Pb}$ and $\mathrm{Zn}$ in the glass industry effluent irrigated soil. Error bars are the standard error of the mean.

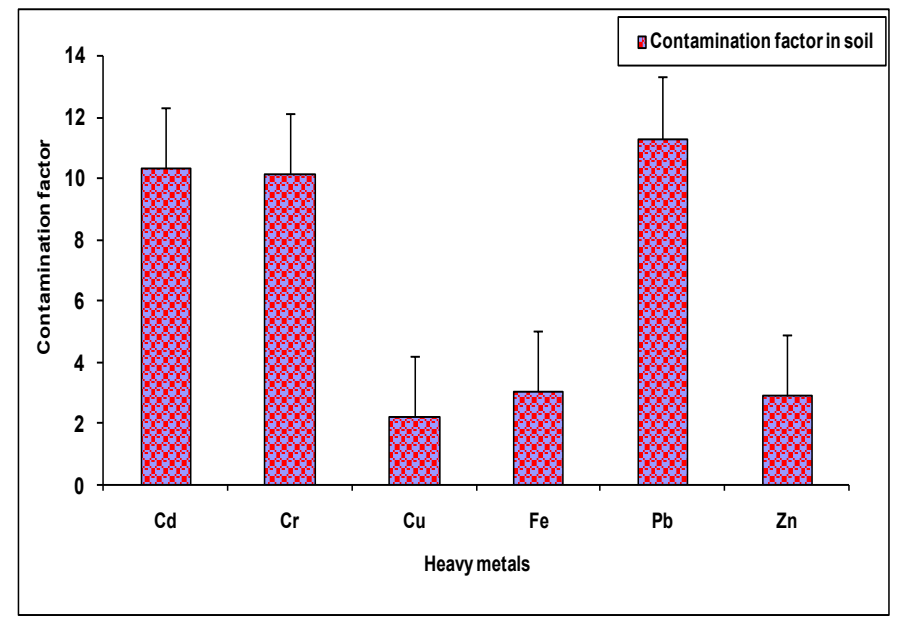

Figure 8: Contamination factor of heavy metals in the soil after disposal of glass industry effluent. Error bars are the standard error of the mean. 
Table 3: Contamination factor (Cf) of various heavy metals in soil after disposal of Glass industry effluent.

\begin{tabular}{|l|c|}
\hline Heavy metals & Contamination factor (Cf) in soil \\
\hline $\mathbf{C d}$ & 10.33 \\
\hline $\mathbf{C r}$ & 10.14 \\
\hline $\mathbf{C u}$ & 2.23 \\
\hline $\mathbf{F e}$ & 3.05 \\
\hline $\mathbf{P b}$ & 11.31 \\
\hline $\mathbf{Z n}$ & 2.93 \\
\hline
\end{tabular}

\section{Conclusion}

The present study concluded that the effluent of glass industry was considerably loaded with different physico-chemical characteristics viz., TS, TDS, TSS, EC, BOD, COD, $\mathrm{Cl}^{-}, \mathrm{Na}^{+}, \mathrm{K}^{+}$, $\mathrm{Ca}^{2+}, \mathrm{Mg}^{2+}, \mathrm{TKN}, \mathrm{PO}_{4}^{3-}$ and $\mathrm{SO}_{4}^{2-}$ and heavy metals viz., $\mathrm{Cd}, \mathrm{Cr}$, $\mathrm{Cu}, \mathrm{Fe}, \mathrm{Pb}$ and $\mathrm{Zn}$. The disposal of effluent significantly $(\mathrm{P}<$ $0.05 / \mathrm{P}<0.01)$ affected the soil characteristics. The values of soil parameters $\mathrm{pH}, \mathrm{EC}, \mathrm{Cl}^{-}, \mathrm{OC}, \mathrm{Na}^{+}, \mathrm{K}^{+}, \mathrm{Ca}^{2+}, \mathrm{Mg}^{2+}, \mathrm{TKN}, \mathrm{PO}_{4}^{3-}$, $\mathrm{SO}_{4}^{2-}, \mathrm{Cd}, \mathrm{Cr}, \mathrm{Cu}, \mathrm{Fe}, \mathrm{Pb}$ and $\mathrm{Zn}$ were significantly $(\mathrm{P}<0.05 / \mathrm{P}<$ 0.01 ) increased after disposal of glass industry effluent in comparison to control soil. Thus, the disposal of glass industry effluent considerably changed the soil quality and affected the natural composition of the soil. Such alterations enhanced the nutrients/ toxicants status of the soil. However, the level of inland disposal should be within the prescribed limit of standards to avoid the development of soil salinity in the long run. Therefore the open land disposal of effluent should be regularly monitored for the alteration of the soil characteristics.

\section{Reference}

[1] Megharaj, M., Avudainayagam, S., Naidu, R. Toxicity of hexavalent chromium and its reduction by bacteria isolated from soil contaminated with tannery waste. (2003) Curr Microbiol 47(1): 51-54.

[2] Samuel, S., Muthukkaruppan, S.M. Physico-chemical analysis of sugar mill effluent, contaminated soil and its effect on seed germination of paddy (Oryza sativa L.). (2011) Int J Pharma Biol Arch 2(5): 14691472.

[3] Jain, C., Singhal, D., Sharma, M. Metal pollution assessment of sediment and water in the river Hindon, India. (2005) Environ Monit Assess 105(1-3): 193-207.

[4] Janardhana Raju, N., Ram, P., Dey, S. Groundwater quality in the lower Varuna River basin, Varanasi district, Uttar Pradesh. (2009) J Geol Soci India 73(2): 178-192.

[5] Kumar, V., Chopra, A.K. Alterations in physico-chemical characteristics of soil after irrigation with paper mill effluent. (2011) J Chem Pharma Res 3(6): 7-22.

[6] Kumar, V., Chopra, A.K. Translocation of micronutrients in French bean (Phaseolus vulgaris L.) grown on soil amended with paper mill sludge. (2012c) J Chem Pharma Res 4(11): 4822-4829.

[7] Kumar, V. Sugar mill effluent utilization in the cultivation of maize (Zea mays L.) in two seasons. (2014a) J Waste Manage: 1-12.

[8] Ahmad, M., Bajahlan, A.S., Hammad, W.S. Industrial effluent quality, pollution monitoring and environmental management. (2008) Environ Monit Assess 147(1-3): 297-306.

[9] Baskaran, L., Sankar, G.K., Chidambaram, A.L.A., et al. Amelioration of sugar mill effluent polluted soil and its effect of green gram (Vigna radiata L.). (2009) Bot Res Int 2 (2): 131-135.

[10] Kumar, V., Chopra, A.K. Pearl millet (Pennisetum Glaucum L.) response after ferti-irrigation with sugar mill effluent in two seasons. (2014d) Int J Recycl Org Waste Agricult 3: 6.
[11] Zafar, S., Aqil, F., Ahmad, I. Metal tolerance and biosorption potential of filamentous fungi isolated from metal contaminated agricultural soil. (2007) Bioresource Technol 98(13): 2557-2561.

[12] Kumar, V., Chopra, A.K. Fertigation effect of distillery effluent on agronomical practices of Trigonella foenum-graecum L. (Fenugreek). (2012a) Environ Monit Assess 184(3): 1207-1219.

[13] Kumar, V., Chopra, A.K. Effect of paper mill effluent irrigation on agronomical characteristics of Vigna radiata (L.) in two different seasons. (2012b) Comm Soil Sci Plant Anal 43(16): 2142-2166.

[14] Kumar, V., Chopra, A.K. Fertigation with agro-residue based paper mill effluent on a high yield spinach variety. (2015) Int J Vege Sci 21(1): 69-97.

[15] Vijayaragavan, M., Prabhahar, C., Sureshkumar, J., et al. Soil irrigation effect of sugar mill effluent on changes of growth and biochemical contents of Raphanus sativus L. (2011) Curr Bot 2(7): 09-13.

[16] Srinivasa, Gowd, S., Kotaiah, B. Groundwater pollution by Cystine manufacturing industrial effluent around the factory. (2000) Environ Geol 39(6): 679-682.

[17] Tandi, N.K., Nyamangara, J., Bangira, C. Environmental and potential health effects of growing leafy vegetables on soil irrigated using sewage sludge and effluent: a case of $\mathrm{Zn}$ and Cu. (2004) J Environ Sci Health 39(3): 461-471.

[18] Perfus Barbeoch, L., Leonhardt, N., Vavasseur, A., et al. Heavy metal toxicity: cadmium permeates through calcium channels and disturbs the plant water status. (2002) The Plant J 32(4): 539-548.

[19] Purushotham, D., Narsing Rao, A., Ravi Prakash, M., et al. Environmental impact on groundwater of Maheshwaram Watershed, Ranga Reddy district, Andhra Pradesh. (2011) J Geol Soci India 77(6): 539548.

[20] Kumar, V., Chopra, A.K. Response of French bean to fertigation with wine from molasses distillery effluent in two seasons. (2014a) Int J Vege Sci 20 (2): 104-123.

[21] Kumar, V., Chopra, A.K. Ferti-irrigation effect of paper mill effluent on agronomical practices of Phaseolus vulgaris (L.) in two different seasons. (2014b) Comm Soil Sci Plant Anal 45(16): 2151-2157.

[22] Kumar, V., Chopra, A.K. Ferti-irrigational response of hybrid cultivar of Indian mustard (Brassica juncea L.) to distillery effluent in two seasons. (2014e) Analy Chem Lett 4(3): 190-206.

[23] Biswas, A.K., Mohanty, M., Hati, K.M., et al. Distillery effluents effect on soil organic carbon and aggregate stability of a Vertisol in India. (2009) Soil Till Res 104(2): 241-246.

[24] Hati, K.M., Biswas, A.K., Bandyopadhyay, K.K., et al. Soil properties and crop yields on a vertisol in India with application of distillery effluent. (2007) Soil Till Res 92(1-2): 60-68.

[25] Kumar, V., Chopra, A.K. Distribution, enrichment and accumulation of heavy metals in soil and Trigonella foenum-graecum L. (Fenugreek) after fertigation with paper mill effluent. (2013b) Open J Metals 3(2): 8-20.

[26] Kumar, V., Chopra, A.K. Accumulation and translocation of metals in soil and different parts of French bean (Phaseolus vulgaris L.) amended with sewage sludge. (2013c) Bull Environ Contam Toxicol 92(1): 103-108.

[27] Shakeri, A., Moore, F., Modaberi, S. Heavy metal contamination and distribution in the Shiraz industrial complex zone soil, South Shiraz, Iran. (2009) World Appl Sci J 6(3): 413-425.

[28] Kumar, V., Chopra, A.K. Ferti-irrigational effect of paper mill effluent on agronomical characteristics of Abelmoschus esculentus L. (Okra). (2013a) Pak J Biol Sci 16(22): 1426-1437.

[29] Kumar, V. Fertigation response of Abelmoschus esculentus L. (Okra) with sugar mill effluent in two different seasons. (2014b) Int J Agrl Sci Res 3(9): 164-180.

[30] Baruah, B.K., Das, M. Study on impact of paper mill effluent on germination behavior and seedling growth of crop plant, Oryza sativa L. (1998) Pollut Res 17(1): 65-68.

[31] Kumar, V., Chopra, A.K. Ferti-irrigational impact of sugar mill effluent on agronomical characteristics of Phaseolus vulgaris (L.) in two seasons. (2014c) Environ Monit Assess 186(11): 7877-7892. 
[32] Kumar, V., Chopra, A.K., Srivastava, S. Distribution, enrichment and accumulation of heavy metals in soil and Vigna mungo L. Hepper (Black gram) after irrigation with distillery wastewater. (2014) J Environ Health Sci 1(1): 1-8.

[33] Werner, V. Glass Chemistry Springer-Verlag Berlin and Heidelberg GmbH \& Co. K. (1994) 2nd revised edition ISBN 3-540-57572-3.

[34] APHA In: Standard Methods for the Examination of Water and Wastewater. American Public Health Association (APHA), American Water Works Association (AWWA) \& Water Environment Federation (WEF), 21st edition, Washington, DC. (2005): 1368.

[35] Chaturvedi, R.K., Sankar, K. Laboratory manual for the physico-chemical analysis of soil, water and plant. (2006) Wildlife Institute of India, Dehradun.

[36] Håkanson, L. An ecological risk index for aquatic pollution control. A sedimentological approach. (1980) Water Res 14(8): 975-1001.

[37] El-Bestawy, E., El-Sokkary, I., Hussein, H., et al. Pollution control in pulp and paper industrial effluents using integrated chemical-biological sequences. (2008) J Indus Microbiol Biotechnol 35(11): 1517-1529. [38] Fazeli, M. S., Khosravan, Hossini, F. M., et al. Enrichment of heavy metals in paddy crops irrigated by paper mill effluents near Nanjangud, Mysore District, Karnataka, India. (1998) J Environ Geol 34(4): 297-302.

[39] Ghaly, M.Y., Jamil, T.S., El-Seey I.E., et al. Treatment of highly polluted paper mill wastewater by solar photocatalytic oxidation with synthesized nano $\mathrm{TiO}_{2}$. (2011) Chemical Eng J 168(1): 446-454.

[40] Howe, Jonathan, Michael, R. Wagner The effect of paper mill wastewater and organic amendments of sodium accumulation by potted cotton woods. (1996) Environ Pollut 92(2): 113-118.
[41] Lacorte, S., Lattorre, A., Barcelo, D., et al. Organic compounds in paper mill process waters and effluents. (2003) Trends Analyt Chem 22(10): 725-737.

[42] Patterson, S. J., Chanasyk D.S., Mapfumo, E., et al. Effect of diluted Kraft pulp mill effluent on hybrid poplar and soil chemical properties. (2008) Irrig Sci 26: 547-560.

[43] Miller, C.E., Turk, L.M. Fundamentals of soil science. Biotech. Books, 1123/74, Trinagar, Delhi. (2002):157.

[44] Haynes, R. J., Naidu, R. Influence of lime fertilizer and manure applications on soil organic matter content and soil physical conditions: a review. (1998) Nutri Cycl Agroecosyst 51: 123-137.

[45] Celik, I. Land use effects on organic matter and physical properties of soil in a southern Mediterranean highland of Turkey. (2005) Soil Till Res 83(2): 270-277.

[46] Mohan, S.C., Samra, J.S., Srivastava, A.K., et al. Training manual on soil conservation and watershed management, Vol-I, soil, Agronomy and socio-economic aspects. (2007) Central soil \& water conservation research \& training institute, Dehradun (U.K) India 42.

[47] Charman, P.E.V., Murphy, B.W. In: Soils: Their Properties and Management. In a Soil Conservation Handbook for New South Wales. (1991) Sydney University Press. Sydney.

[48] Ramulu, S.U.S. Reuse of municipal sewage and sludge in agriculture. (2001) Scientific publishers (India), Jodhpur: 86.

[49] BIS In: Indian standards for drinking water specification (BIS 10500:1991) retrieved on 20th April, 2007.

[50] Mohammadi, A. Torkashvand, Haghighat, N., et al. Effect of paper mill lime sludge as an acid soil amendment. (2010) Scient Res Essays 5(11): 1302-1306.
Ommega Online Publishers

Journal Title: Journal of Environment and Health Science (JEHS)

Journal Short Name: J Environ Health Sci
Journal ISSN: 2378-6841

E-mail: environmentalscience@ommegaonline.org

Website: www.ommegaonline.org 